\title{
Nociceptin/Orphanin FQ Content is Decreased in Forebrain Neurones During Acute Stress
}

\author{
D. P. Devine, ${ }^{*}$ M. T. Hoversten, $\dagger$ Y. Ueda $\dagger$ and H. Akil $\dagger$ \\ *Department of Psychology, University of Florida, Gainesville, FL, USA. \\ †Mental Health Research Institute, University of Michigan, Ann Arbor, MI, USA.
}

Key words: stress, HPA axis, ACTH, corticosterone, opioid.

\begin{abstract}
We examined the effects of acute and chronic stress on neurotransmission of nociceptin/orphanin FQ (N/OFQ) in a variety of brain regions. Four groups of rats were exposed to chronic variable stress, and/or a single acute stress before decapitation. Group 1 served as unstressed controls. The rats in group 2 (chronic stress/no acute stress) were exposed to a 10-day regimen of chronic stress (two unpredictable stressors per day). These rats were decapitated $20 \mathrm{~h}$ after the last stressor. The rats in group 3 (no chronic stress/acute stress) were not exposed to chronic stress, but they were restrained for 30 min prior to decapitation. The rats in group 4 (chronic stress/acute stress) were chronically stressed for 10 days, and were then restrained prior to decapitation. Trunk blood was collected, and plasma adrenocorticotrophic hormone (ACTH) and corticosterone (CORT) were assayed by radioimmunoassay (RIA). The rats' brains were dissected, and N/OFQ content was measured by RIA in a variety of brain regions, and in spinal cord. Chronic stress exposure altered the hormonal responses to the acute stress exposure. In the rats that were exposed to chronic stress without acute stress (group 2), N/OFQ content did not differ from the content of the unstressed controls in any of the dissected brain regions. In the two groups that were stressed acutely just before decapitation (groups 3 and 4), N/OFQ content was decreased by $25-30 \%$ in the basal forebrain. Accordingly, the neuronal content of N/OFQ is decreased in basal forebrain neurones during acute stress exposure. In light of our previous finding that N/OFQ administration increases circulating ACTH and CORT concentrations, and augments hormonal responses to an acute stressor, the current finding raises the possibility that endogenous N/OFQ participates in neuronal regulation of hormonal responses to acute stress exposure.
\end{abstract}

Nociceptin/orphanin FQ (N/OFQ) is a 17 -amino acid peptide that is evolutionarily related to the opioid family of neuropeptide transmitters $(1,2)$. It exhibits a high degree of amino acid sequence homology with the opioid peptides (especially dynorphin $\mathrm{A}_{1-17}$ ), but does not bind to the $\mu$-, $\delta$ - and $\kappa$-opioid receptor types. Rather, it binds saturably and with high affinity to the NOP receptor (formerly known as ORL1 or LC132). NOP is a member of the super family of Gi protein-coupled receptors that contain seven trans-membrane alpha helices. It is negatively linked to adenylate cyclase, activates inward rectifying $\mathrm{K}^{+}$channels and inhibits $\mathrm{N}$-type $\mathrm{Ca}^{2+}$ channels (3-10). NOP exhibits a high degree of amino acid sequence homology with the cloned $\mu-, \delta$ - and $\kappa$ opioid receptors, particularly in the trans-membrane and cytosolic domains (approximately 85\% homology in the intracellular loop between trans-membrane 5 and 6) (9). However, despite the structural and functional similarities between NOP and the opioid receptors, NOP does not selectively bind prototypical opioid agonists or antagonists $(3,4,8-10)$. Accordingly, N/OFQ and
NOP represent an opioid-related neurotransmitter system that has the potential to mediate physiological and behavioural actions distinct from those that are mediated by the opioid system. The range of physiological and behavioural actions that are mediated by the N/OFQ-NOP system has not been fully characterized.

N/OFQ and NOP (and their respective mRNAs) are ubiquitously expressed in mammalian brain and spinal cord (11-13), and are particularly abundant within a variety of limbic structures (3, $4,8,10-16)$. Furthermore, functional activity of N/OFQ has been demonstrated in these limbic structures by means of $\left[{ }^{35} \mathrm{~S}\right] \mathrm{GTP} \gamma \mathrm{S}$ autoradiography (17-19). This neuroanatomical and physiological association between the N/OFQ system and limbic sites raises the possibility that N/OFQ neurotransmission may participate in processing of emotional stimuli.

We recently reported that intracerebroventricular (i.c.v.) microinjections of N/OFQ produce increases in plasma adrenocorticotrophic hormone (ACTH) and corticosterone (CORT) concentrations in unstressed rats. Furthermore, the i.c.v. N/OFQ 
microinjections enhanced and prolonged the stress-induced elevations in plasma ACTH and CORT concentrations when rats were exposed to an acute mild stressor (20). In light of these effects of N/OFQ on stress-related hormone secretion, we developed a radioimmunoassay (RIA) for $\mathrm{N} / \mathrm{OFQ}$, and used it to examine the effect of chronic and acute stress on neurotransmission of endogenous N/OFQ in various regions of the rat brain. Our chronic stress regimen was designed to focus on manipulations in which aversive stimuli are presented in an unpredictable manner, which is a regimen that we believe resembles the unpredictability and loss of environmental control that constitute typical stressors experienced by humans. Accordingly, the stress regimen included presentation of stressors at variable times of the day, and in an unpredictable order.

\section{Materials and methods}

\section{Animals and stress procedures}

Thirty-two male Sprague-Dawley rats, weighing $260-300 \mathrm{~g}$, were pair-housed in $43 \times 21.5 \times 25.5 \mathrm{~cm}$ plexiglas cages, and maintained on a $12: 12 \mathrm{~h}$. light $/$ dark cycle (lights on at $08.00 \mathrm{~h}$ ). Food and water were available ad libitum. All the procedures were carried out in accordance with the Guide for the Care and Use of Laboratory Animals.

After 10 days acclimation to the housing room, the rat pairs were randomly assigned to four treatment groups (eight rats per group), wherein each of the rats that were housed together in a pair were assigned the same treatment. Group 1 served as untreated controls, remaining in the housing room without intervention (other than cage maintenance) for 10 additional days. On the morning of the eleventh day, these rats were rapidly sacrificed by decapitation. The rats in group 2 (chronic stress/no acute stress) were exposed to a regimen of chronic variable stressors for 10 days (two stressors per day) and sacrificed by decapitation on day $11,20 \mathrm{~h}$ after their last stress exposure. The rats in group 3 (no chronic stress/acute stress) remained in the housing room without intervention for 10 days. On the morning of the eleventh day, these rats were placed in a restraint tube for $30 \mathrm{~min}$, and then immediately sacrificed by decapitation. The rats in group 4 (chronic stress/ acute stress) were exposed to the chronic variable stress regimen for 10 days. On the morning of the eleventh day, these rats were restrained for $30 \mathrm{~min}$, and then immediately sacrificed by decapitation. All the rats were decapitated between $09.30 \mathrm{~h}$ and $10.00 \mathrm{~h}$, a time at which the rats' circadian plasma ACTH and CORT concentrations were at their daily nadir (21). The group assignments and stress regimen are summarized in Table 1.

Immediately after decapitation, trunk blood was collected from each rat $(6 \mathrm{ml}$ per rat) on ice into polyethylene tubes containing $600 \mu \mathrm{l}\left(\mathrm{Na}_{2}\right.$-EDTA) at $20 \mu \mathrm{g} / \mu \mathrm{l}$. Blood samples were centrifuged at $4{ }^{\circ} \mathrm{C}$ for $5 \mathrm{~min}$ at 2800 r.p.m. The plasma fraction was isolated, aliquotted, and frozen at $-80^{\circ} \mathrm{C}$. The adrenal and thymus glands were collected and weighed, and each rats' brain was removed and dissected on ice according to the method of Glowinski and Iversen (22). Briefly, each brain was dissected to isolate the cerebellum, hindbrain (medulla and pons), hypothalamus, whole cortex, septal area, hippocampus, basal forebrain (including caudate nucleus, nucleus accumbens, globus pallidus, ventral pallidum, and bed nucleus of stria terminalis, BNST), thalamus, midbrain and olfactory bulbs. Pineal glands, pituitary glands and spinal cords were also removed. The dissected brain regions, pineal glands, pituitaries, and spinal cords were frozen on dry ice and stored at $-80^{\circ} \mathrm{C}$.

\section{Assays for plasma ACTH and CORT}

Plasma ACTH concentrations were quantified by immunoradiometric assay, using a kit from Nichols Institute Diagnostics (San Juan Capistrano, CA, USA). Plasma CORT concentrations were quantified RIA using a highly specific antibody developed in our laboratory and characterized by Dr D. L. Helmreich (23). Crossreactivities to related compounds (e.g. cortisol) were less than $3 \%$. Intra-assay and interassay variations were less than $5 \%$.

\section{Characterization of RIA for N/OFQ}

We established a highly specific RIA to assay content of N/OFQ in brain, pituitary and spinal cord. The assay uses a specific N/OFQ antiserum (rabbit \#216, bleed \#6)
TABLE 1. Group Assignments and Treatment Regimens.

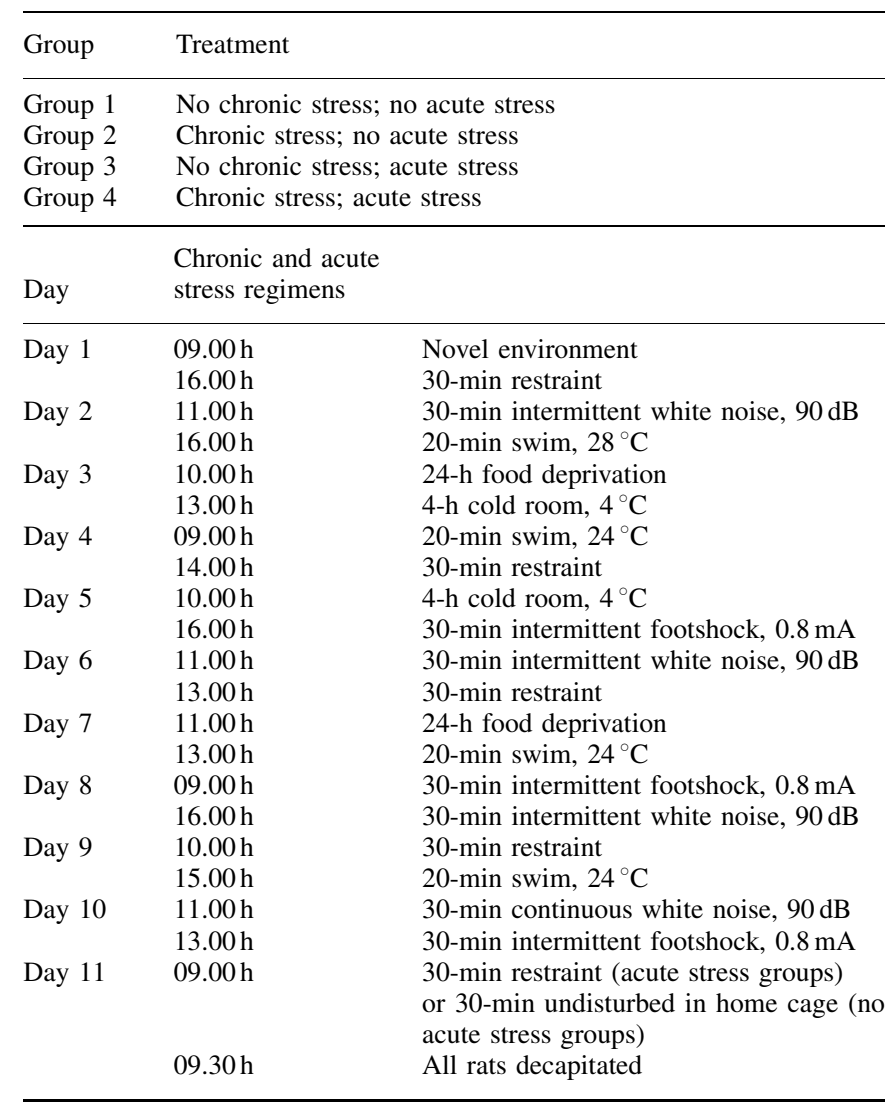

at a dilution of $1: 200000$. The $\mathrm{IC}_{50}$ is $30-80$ pmol. This assay appears to be highly selective, as determined by its lack of affinity for synthetic peptides. Neither N/OFQ (1-11) nor N/OFQ (11-17) could displace the binding of the full labelled N/OFQ, suggesting that the antiserum does not see the $N$-terminus nor the $C$-terminus exclusively, and most likely requires the intact mid-portion of the molecule. The binding could not be displaced by a large number of peptides tested, including structurally related opioid peptides (data not shown). The limit of detection for N/ OFQ was approximately $10 \mathrm{fmol} / \mathrm{ml}$.

The assay was characterized chromatographically and biochemically, using pooled brain regions from five additional rats (pooling was necessary for the chromatographic characterization). These various pooled brain regions were homogenized in ice cold $\mathrm{MeOH} / 0.1 \mathrm{~N} \mathrm{HCl}(1: 1)$ to extract N/OFQ. Homogenates were centrifuged at 12000 r.p.m. for $30 \mathrm{~min}$, supernatants were evaporated, and tissue extracts were resuspended in RIA buffer. Resuspended tissue extracts were molecularly sieved by application to a precalibrated G50-50 Sephadex column $(1.5 \times 90 \mathrm{~cm})$ developed with $1 \%$ formic acid $/ 0.01 \%$ bovine serum albumin at $4{ }^{\circ} \mathrm{C}$, and fractions $(1.5 \mathrm{ml})$ were collected. One portion of these fractions was tested by RIA to identify the active peaks. The remainders of the fractions from a given peak were pooled, lyophilized, and dissolved in $0.1 \% \mathrm{TFA} / 5 \% \mathrm{CH}_{3} \mathrm{CN}$. Highperformance liquid chromatography (HPLC) analysis was performed on these remaining fractions using a reverse phase $\mathrm{C} 4$ column $(0.46 \mathrm{~cm} \times 250 \mathrm{~cm})$, developed in a linear gradient from $0 \%$ to $42 \%$ solvent B, in $40 \mathrm{~min}$ (A: $0.1 \% \mathrm{TFA} / 5 \%$ $\mathrm{CH} 3 \mathrm{CN}$; $\mathrm{B}: 0.1 \%$ TFA in $\mathrm{CH}_{3} \mathrm{CN}$ ). N/OFQ eluted at $22 \mathrm{~min}$ from these active fractions, with the HPLC pump set at a flow rate of $1.0 \mathrm{ml} / \mathrm{min}$.

\section{N/OFQ RIA from brain regions, pituitaries and spinal cords}

Dissected brain regions were processed for RIA to assess N/OFQ content, using our highly specific antibody. The dissected brain regions were thawed, individually homogenized in ice-cold $\mathrm{MeOH} / 0.1 \mathrm{~N} \mathrm{HCl}(1: 1)$, followed by centrifugation at 12000 r.p.m. for $30 \mathrm{~min}$ Supernatants were evaporated and tissue extracts were resuspended in RIA buffer. These re-suspended tissue extracts were sieved as previously described and processed for RIA. 
Statistical analysis

Between-groups differences in adrenal and thymus weights were each analysed using one-way analyses of variance (ANOVA). All significant effects were further analysed with Scheffé post tests, comparing values for each stressed group, with the corresponding value for the unstressed control group (group 1), and comparing relevant between-groups differences among the various stressed groups. Betweengroups differences in plasma ACTH concentrations, in plasma CORT concentrations, and in regional N/OFQ content for each region, were each analysed using oneway ANOVA and Scheffé post tests in the same manner as in analyses of adrenal and thymus weights.

\section{Results}

The unstressed control group (group 1) provided basal measures of adrenal and thymus weights (Fig. 1) and plasma ACTH and CORT concentrations (Fig. 2). This unstressed group also provided basal measures of the regional N/OFQ content from rat brain, spinal cord, and pineal and pituitary glands (Table 2).
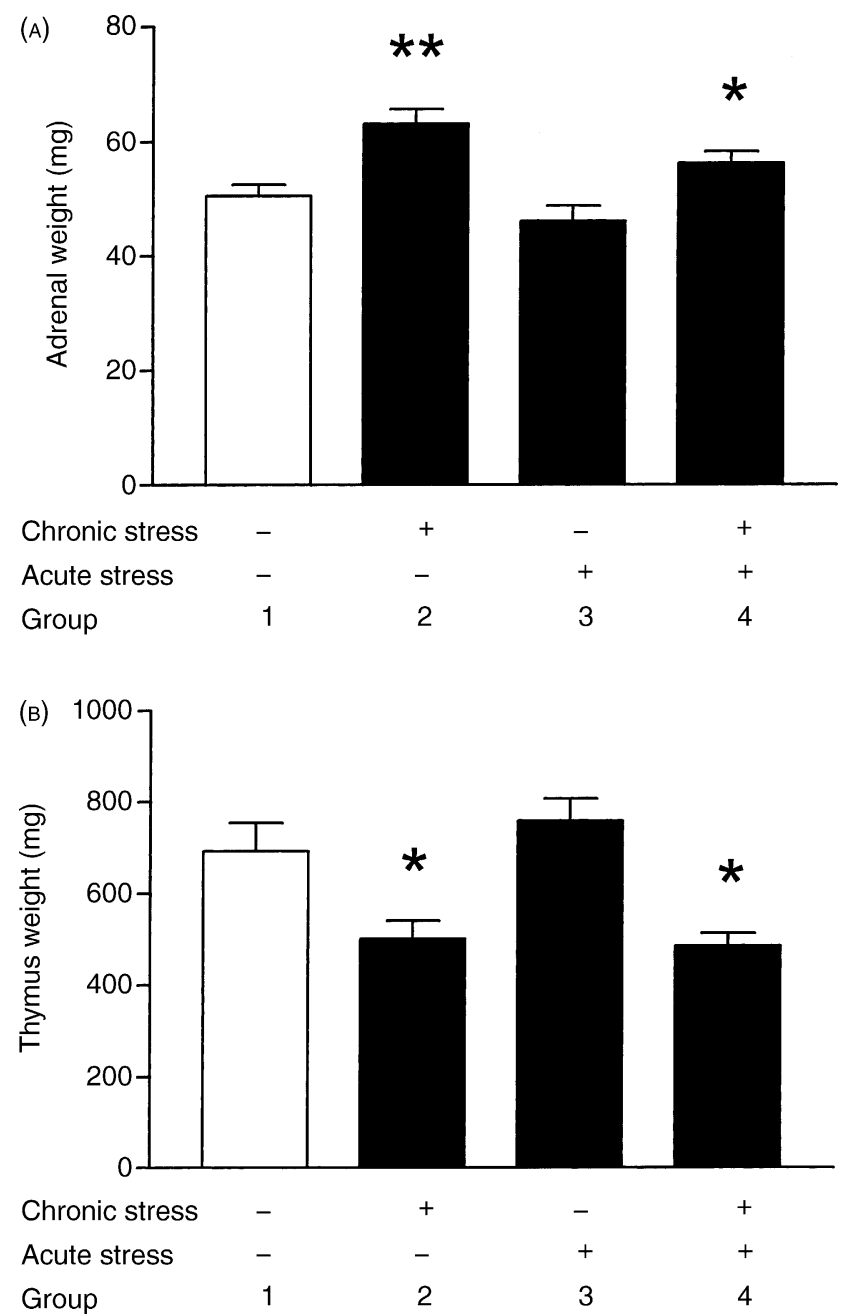

FIG. 1. The chronic variable stress regimen produced substantial alterations in adrenal and thymus gland masses. (A) Adrenal gland weights were significantly greater in chronically stressed rats (groups 2 and 4) than they were in the unstressed controls (group 1) $[\mathrm{F}(3,28)=9.88, \mathrm{P}<0.01]$. (B) Thymus gland weights were significantly less in chronically stressed rats than they were in the unstressed controls $[\mathrm{F}(3,28)=8.82, \mathrm{P}<0.01]$. Values expressed are group means \pm SEM ( $n=8$ rats per group). Significant differences between chronically stressed rats and untreated controls (Scheffé tests) are depicted $\left({ }^{*} \mathrm{P}<0.05,{ }^{* *} \mathrm{P}<0.01\right)$.
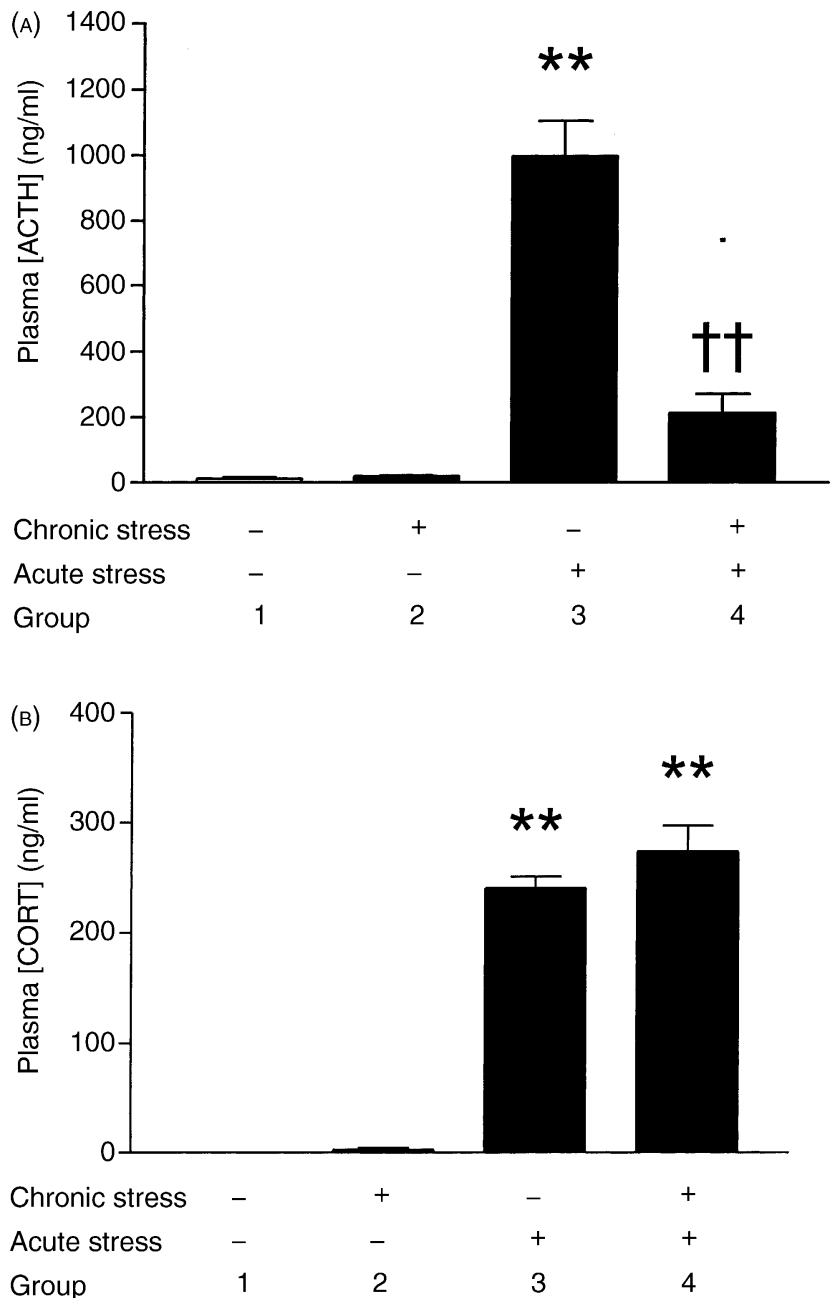

FIG. 2. Acute restraint stress produced substantial elevations in plasma adrenocorticotrophic hormone (ACTH) and corticosterone (CORT) concentrations, and these effects differed between the acutely stressed groups. (A) Plasma ACTH concentrations were significantly greater in acutely stressed rats (groups 3 and 4) than they were in the unstressed controls (group 1) $[\mathrm{F}(3,28)=56.16, \mathrm{P}<0.01]$, and this stress-induced elevation in ACTH concentrations was greater in the rats that had not been previously stressed (group 3) than it was in the rats that had been chronically stressed (group 4). (B) Plasma CORT concentrations were significantly greater in acutely stressed rats than they were in the unstressed controls $[\mathrm{F}(3,28)=131.49$, $\mathrm{P}<0.01]$, and this stress-induced elevation in CORT concentrations was greater in the rats that had been chronically stressed (group 4) than it was in the rats that had not been stressed previously (group 3). Values expressed are group means \pm SEM ( $n=8$ rats per group). Significant differences between acutely stressed rats and untreated controls (Scheffé tests) are depicted $\left({ }^{*} \mathrm{P}<0.05,{ }^{* *} \mathrm{P}<0.01\right)$. Significant differences between acutely stressed groups that were or were not chronically stressed (groups 3 and 4; Scheffé tests) are also depicted $(\dagger \dagger \mathrm{P}<0.01)$.

The rats in the chronically stressed groups (groups 2 and 4) had significantly larger adrenal glands and significantly smaller thymus glands than did the rats (group 1) that were not stressed. Furthermore, adrenal and thymus weights did not differ between the rats (group 3 ) that were exposed to acute but not chronic stress, and the unstressed (group 1) control rats (Fig. 1).

Plasma ACTH and CORT concentrations did not differ between the chronically stressed rats that were not exposed to acute stress prior to decapitation (group 2) and the unstressed (group 1) control rats (Fig.2). However, the plasma ACTH and CORT 
TABLE 2. N/OFQ Contents Assayed by Radioimmunoassay in Dissected Brain Regions (fmol/mg tissue $\pm \mathrm{SEM}$ ).

\begin{tabular}{|c|c|c|c|c|}
\hline Brain region & Group 1 (baseline) ${ }^{*}$ & Group 2 & Group 3 & Group 4 \\
\hline Pituitary & Not detected & Not detected & Not detected & Not detected \\
\hline Pineal & Not detected & Not detected & Not detected & Not detected \\
\hline Olfactory bulb & $0.6788 \pm 0.0391$ & $0.7130 \pm 0.0544$ & $1.6164 \pm 0.7109$ & $0.7130 \pm 0.0702$ \\
\hline Cerebellum & $1.0789 \pm 0.3998$ & $0.8304 \pm 0.2795$ & $1.2326 \pm 0.3405$ & $0.9505 \pm 0.3020$ \\
\hline Basal forebrain & $1.6555 \pm 0.1600$ & $1.6161 \pm 0.1453$ & $1.1565 \pm 0.1005$ & $1.2509 \pm 0.0988$ \\
\hline Cortex & $2.1221 \pm 0.1039$ & $2.4156 \pm 0.1195$ & $2.0336 \pm 0.1416$ & $2.1391 \pm 0.1052$ \\
\hline Spinal cord & $3.0831 \pm 0.3057$ & $2.9611 \pm 0.1343$ & $2.6060 \pm 0.1986$ & $2.8803 \pm 0.2542$ \\
\hline Hippocampus & $3.2506 \pm 0.3021$ & $3.0123 \pm 0.2018$ & $3.0686 \pm 0.2512$ & $3.1778 \pm 0.2638$ \\
\hline Hindbrain & $7.3643 \pm 0.3901$ & $10.9794 \pm 2.1885$ & $7.8311 \pm 1.2250$ & $7.0520 \pm 0.3570$ \\
\hline Thalamus & $8.6499 \pm 0.4874$ & $8.8725 \pm 0.6858$ & $8.5015 \pm 0.8023$ & $8.3075 \pm 0.6380$ \\
\hline Midbrain & $15.7538 \pm 0.5966$ & $11.1664 \pm 0.4365$ & $9.6939 \pm 0.9200$ & $10.3195 \pm 0.4306$ \\
\hline Septum & $17.3688 \pm 0.6988$ & $18.7283 \pm 1.4921$ & $20.1389 \pm 2.4436$ & $17.9564 \pm 1.6685$ \\
\hline Hypothalamus & $19.5024 \pm 1.5364$ & $20.1999 \pm 1.9030$ & $18.5819 \pm 1.8918$ & $18.5808 \pm 1.1456$ \\
\hline
\end{tabular}

${ }^{*}$ Data from group 1 represent measures in rats that were not exposed to chronic or acute stressors $(n=8)$, and thus depict baseline values. These values indicate the resting distribution of N/OFQ in gross regions of rat brain, measured by radioimmunoassay.

concentrations of acutely stressed rats (groups 3 and 4) differed significantly from the unstressed (group 1) controls. Furthermore, the ACTH concentrations in the acutely stressed rats that had been exposed to chronic stress (group 4) differed significantly from the concentrations in the acutely stressed rats (group 3) that were not exposed to chronic stress (Fig. 2). In this case, the chronically stressed rats (group 4) exhibited lower plasma ACTH concentrations after acute stress than did the rats that were not chronically stressed (group 3). There were no significant differences in the CORT responses to acute stress between groups 3 and 4 .

The regional N/OFQ contents of all groups are indicated in Table 2. Regardless of the stress exposures, N/OFQ contents did not differ between groups for most of the brain regions and for the spinal cords. N/OFQ contents of the pineals and pituitaries were below the detection limit of the RIA. There was no effect of chronic stress alone on N/OFQ tissue content in any dissected brain region. However, the rats in the acutely stressed groups

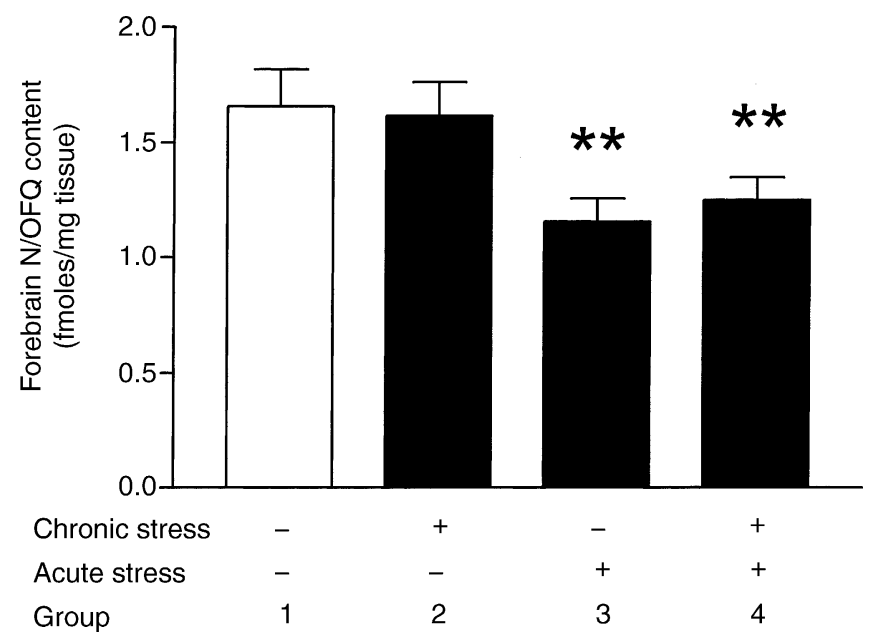

FIG. 3. Acute restraint stress produced substantial decreases in forebrain N/ OFQ content, assayed by radioimmunoassay, and these effects were equivalent between the acutely stressed groups that were or were not exposed to chronic variable stress $[\mathrm{F}(3,28)=3.85, \mathrm{P}<0.01]$. Values expressed are group means \pm SEM ( $n=8$ rats per group). Significant differences between chronically stressed rats and untreated controls (Scheffé tests) are depicted $\left({ }^{* *} \mathrm{P}<0.01\right)$ (groups 3 and 4) exhibited significantly decreased tissue N/OFQ content (approximately 25-30\% decrease) in the basal forebrain region (Fig. 3). Furthermore, the basal forebrain N/OFQ contents did not differ between these two acutely stressed groups, despite their differing chronic stress histories.

\section{Discussion}

The basal N/OFQ contents that are listed in Table 2 (values from group 1) indicate the overall amount of neuronal N/OFQ peptide in brain regions and spinal cords of unstressed rats. A previous neuroanatomical analysis characterized the distribution of N/OFQ using immunohistochemistry, and the distribution of N/OFQ mRNA using in situ hybridization (13). In agreement with that report, we found that N/OFQ-containing neurones are widely distributed in the rat brain and spinal cord, and N/OFQ content is particularly high in some brain regions that are associated with limbic functions (e.g. hippocampus, septum and hypothalamus). N/OFQ content was at or below detection limits in the pituitary and pineal glands, and at intermediate levels throughout other brain regions, including forebrain, cerebellum, whole cortex and spinal cord.

The data in Table 2 show that N/OFQ content was not changed to a detectable degree in most regions during acute stress exposure. However, limitations of the assay may have yielded false negative results in some regions. Whereas the RIA is very highly sensitive to N/OFQ, the technique of dissecting the brain into gross regions may have obscured some effects. Within any given brain region, there could be multiple populations of N/OFQcontaining neurones, and these populations may differ in their responsiveness to the stress exposure. Because stress-induced changes in N/OFQ content could have occurred only in a subpopulation of the total N/OFQ-containing neurones in a particular brain region, and total N/OFQ from the entire region was applied to the RIA, any change in N/OFQ content might be masked by the contribution of neurones in which the content was not altered. On the other hand, the large (25-30\%) decreases that occurred in basal forebrain during acute stress (groups 3 and 4) (Fig.3) suggest that either a large population of N/OFQ containing neurones expressed a moderate decrease in N/OFQ content, or a small population of these basal forebrain neurones expressed a 
very large decrease in neuronal N/OFQ. The dissected basal forebrain region contains a heterogeneous set of nuclei (including caudate, putamen, accumbens, pallidum and BNST), and most of these nuclei exhibit substantial N/OFQ immunoreactivity (13). Accordingly, it appears that the detected decreases in this dissected region may represent substantial changes in content within a subset of the total N/OFQ-containing neurones in the region. We cannot be certain as to any specific locus of these changes in N/ OFQ content, but we are continuing to study the neuroanatomical specificity of the interactions between stress and N/OFQ function.

The decreased N/OFQ content that was identified in basal forebrain after acute stress indicates that N/OFQ neurotransmission is altered by the stress exposure in some neurones of this brain region. This alteration could derive from decreases in N/OFQ biosynthesis, increases in N/OFQ release, and/or increases in enzymatic degradation of N/OFQ stores. In light of the short time course of the effect (within $30 \mathrm{~min}$ of stress exposure), and the large magnitude of the decrease, we suspect that increased release is a likely candidate mechanism. However, decreased synthesis and/or increased degradation might also account for the observed stress-induced decreases in N/OFQ content either alone or in combination with increased release of N/OFQ.

The regimen of chronic variable stress produced an interesting set of adaptations in hypothalamic-pituitary-adrenal (HPA) axis functioning, as well as a dynamic set of N/OFQ responses in neurones of the basal forebrain. The chronically stressed rats (groups 2 and 4) exhibited pronounced thymus involution and adrenal hypertrophy, which are well-known consequences of chronic stress $(24,25)$. In addition, the chronically stressed rats that were exposed to an acute stressor (group 4) had a blunted ACTH response to the acute stressor compared to the response in rats that only experienced the acute stressor (group 3). Overall, these adaptations indicate that the chronic variable stress regimen had substantial effects on physiological regulation of the HPA axis and associated organs in these rats. In contrast to these alterations in function of the HPA axis, the overall steady state of N/OFQ function in the basal forebrain appeared to be quite stable. Acute stress decreased basal forebrain N/OFQ content (a situation that was apparently repeated over and over again with each stress exposure during the chronic stress regimen), especially as the restraint stress that was used as the acute stressor was also used repeatedly as part of the chronic variable stress regimen. However, neuronal stores of N/OFQ appear to have been replenished because the chronically stressed rats of group 2 did not differ in neuronal N/OFQ content from the unstressed rats in group 1. Furthermore, the basal forebrain N/OFQ responses to acute stress did not differ between the rats that were chronically stressed (group 4) and those that were not chronically stressed (group 3) before exposure to the acute stressor. Taken together, these findings suggest that the stress-responsive N/OFQ system is a tightly regulated system wherein increased use results in neuroadaptive responses to maintain basal functioning within normal limits.

The current finding that N/OFQ content is altered in response to acute stress supports the possibility that endogenous N/OFQ may play a role in physiological responses to stress. This possibility is further supported by our previous finding that i.c.v. administration of N/OFQ increases circulating ACTH and CORT concentrations in quiescent rats, and augments HPA responses in mildly stressed rats (20). Furthermore, we recently identified that N/OFQ microinjections directly into the BNST (a region that is included in the basal forebrain dissections of the current experiment) produce substantial increases in circulating ACTH and CORT concentrations (26). In addition, N/OFQ knockout mice exhibit an altered CORT response after exposure to mild stress (27). However, the mechanism(s) whereby acute stress-induced alterations in N/OFQ function might in turn input to regulation of the HPA axis are unknown. In light of the fact that N/OFQ administration activates the HPA axis, and N/OFQ is generally thought to exert inhibitory actions on neurones $(3,4)$, N/OFQ-induced activation of the HPA axis likely results from an as yet unidentified disinhibitory action, ultimately producing elevated release of ACTH from pituitary corticotrope cells. The potential that endogenous N/OFQ responses to acute stress might contribute to HPA axis regulation requires further examination.

In summary, acute exposure to stress induced a decrease in content of N/OFQ from neurones in the basal forebrain. This decreased neuronal N/OFQ content is indicative of stress-induced alterations in synthesis, release, and/or processing of N/OFQ. The fact that N/OFQ stores returned to normal levels shortly after exposure to chronic variable stress suggests that the stress-responsive N/OFQ containing neurones of the basal forebrain are tightly regulated. In conjunction with previous studies, the data indicate that stress-induced alterations in N/OFQ neurotransmission may participate in regulation of the HPA axis. We are continuing to localize these interactions between stress and N/OFQ neurotransmission, and to characterize the potential role that N/OFQ may play in stress responses.

\section{Acknowledgements}

This research was funded by NIDA grants DA02265-17 and DA08920-02, and by a donation from the Markey Charitable trust \#88-46.

Accepted 26 August 2002

\section{References}

1 Reinscheid RK, Nothacker H-P, Bourson A, Ardati A, Henningsen RA, Bunzow JR, Grandy DK, Langen H, Monsma FJ Jr, Civelli O, Orphanin FQ. A neuropeptide that activates an opioid-like G-protein-coupled receptor. Science 1995; 270: 792-794.

2 Meunier JC, Mollereau C, Toll L, Suaudeau C, Moisand C, Alvinerie P, Butour J-C, Guillemot J-C, Ferrara P, Monsarrat B, Mazargull H, Vassart G, Parmentier M, Costentin J. Isolation and structure of the endogenous agonist of opioid receptor-like $\mathrm{ORL}_{1}$ receptor. Nature 1995; 377: 532-535.

3 Bunzow JR, Saez C, Mortrud M, Bouvier C, Williams JT, Low M, Grandy DK. Molecular cloning and tissue distribution of a putative member of the rat opioid receptor gene family that is not a $\mu, \delta$ or $\kappa$ opioid receptor type. FEBS Lett 1994; 347: 284-288.

4 Mollereau C, Parmentier M, Mailleux P, Butour J-L, Moisand C, Chalon P, Caput D, Vassart G, Meunier JC. ORL1, a novel member of the opioid receptor family - cloning, functional expression and localization. FEBS Lett 1994; 341: 33-38.

5 Vaughan CW, Christie MJ. Increase by the ORL1 receptor (opioid receptor-like1) ligand, nociceptin, of inwardly rectifying $\mathrm{K}$ conductance in dorsal raphe nucleus neurones. Br J Pharmacol 1996; 117: 1609-1611.

6 Connor M, Yeo A, Henderson G. The effect of nociceptin on $\mathrm{Ca}^{2+}$ channel current and intracellular $\mathrm{Ca}^{2+}$ in the SH-SY5Y human neuroblastoma cell line. Br J Pharmacol 1996; 118: 205-207.

7 Connor M, Vaughan CW, Chieng B, Christie MJ. Nociceptin receptor coupling to a potassium conductance in rat locus coeruleus neurones in vitro. Br J Pharmacol 1996; 119: 1614-1618.

8 Fukuda K, Kato S, Mori K, Nishi M, Takeshima H, Iwabe N, Miyata T, Houtani T, Sugimoto T. cDNA cloning and regional distribution of a novel member of the opioid receptor family. FEBS Lett 1994; 343: 42-46. 
9 Chen Y, Fan Y, Liu J, Mestek A, Tian M, Kozak CA, Yu L. Molecular cloning, tissue distribution and chromosomal localization of a novel member of the opioid receptor gene family. FEBS Lett 1994; 347: 279-283.

10 Lachowicz JE, Shen Y, Monsma FJ Jr, Sibley DR. Molecular cloning of a novel $\mathrm{G}$ protein-coupled receptor related to the opiate receptor family. $J$ Neurochem 1995; 64: 34-40.

11 Anton B, Fein J, To T, Li X, Silberstein L, Evans CJ. Immunohistochemical localization of ORL-1 in the central nervous system of the rat. J Comp Neurol 1996; 368: 229-251.

12 Neal CR Jr, Mansour A, Reinscheid RK, Nothacker HP, Civelli O, Akil H, Watson SJ Jr. Opioid receptor-like (ORL1) receptor distribution in the rat central nervous system: comparison of ORL1 receptor mRNA expression with $\left({ }^{125}\right) \mathrm{I}-\left[\left({ }^{14}\right) \mathrm{Tyr}\right]$-orphanin FQ binding. J Comp Neurol 1999; 412: 563-605.

13 Neal CR Jr, Mansour A, Reinscheid RK, Nothacker HP, Civelli O, Watson SJ Jr. Localization of orphanin FQ (nociceptin) peptide and messenger RNA in the central nervous system of the rat. J Comp Neurol 1999; 406: 503-547.

14 Wick MJ, Minnerath SR, Lin X, Elde R, Law P-Y, Loh HH. Isolation of a novel cDNA encoding a putative membrane receptor with high homology to the cloned $\mu, \delta$, and $\kappa$ opioid receptors. Mol Brain Res 1994; 27: 37-44.

15 Florin S, Leroux-Nicollet I, Meunier JC, Costentin J. Autoradiographic localization of $\left[{ }^{3} \mathrm{H}\right]$ nociceptin binding sites from telencephalic to mesencephalic regions of the mouse brain. Neurosci Lett 1997; 230: 33-36.

16 Foddi MC, Mennini T. $\left[{ }^{125} \mathrm{I}\right]\left[\mathrm{Tyr}^{14}\right]$ orphanin binding to rat brain: evidence for labelling the opioid-receptor-like 1 (ORL1). Neurosci Lett 1997; 230: 105-108.

17 Shimohira I, Tokuyama S, Himeno A, Niwa M, Ueda H. Characterization of nociceptin-stimulated in situ $\left[{ }^{35} \mathrm{~S}\right] \mathrm{GTP} \gamma \mathrm{S}$ binding in comparison with opioid agonist-stimulated ones in brain regions of the mice. Neurosci Lett 1997; 237: 113-116.

18 Sim LJ, Childers SR. Anatomical distribution of mu, delta, and kappa opioid- and nociceptin/orphanin FQ-stimulated $\left[{ }^{35} \mathrm{~S}\right]$ guanylyl-5'-O-
( $\gamma$-thio)-triphosphate binding in guinea pig brain. J Comp Neurol 1997; 386: 562-572.

19 Sim LJ, Xiao RY, Childers SR. Identification of opioid receptor-like (ORL1) peptide-stimulated $\left[{ }^{35} \mathrm{~S}\right] \mathrm{GTP} \gamma \mathrm{S}$ binding in rat brain. Neuroreport 1996; 7: 729-733.

20 Devine DP, Watson SJ, Akil H. Orphanin FQ regulates neuroendocrine function of the limbic-hypothalamic-pituitary-adrenal axis. Neuroscience 2001; 102: 541-553.

21 Kwak SP, Morano MI, Young EA, Watson SJ, Akil H. Diurnal CRH mRNA rhythm in the hypothalamus: decreased expression in the evening is not dependent on endogenous glucocorticoids. Neuroendocrinology 1993; 57: 96-105.

22 Glowinski J, Iversen LL. Regional studies of catecholamines in the rat brain. I. The disposition of $\left[{ }^{3} \mathrm{H}\right]$ norepinephrine, $\left[{ }^{3} \mathrm{H}\right]$ dopamine and $\left[{ }^{3} \mathrm{H}\right]$ dopa in various regions of the brain. J Neurochem 1966; 13: 655-669.

23 Helmreich DL, Morano MI, Akil H, Watson SJ. Correlation between changes in stress-induced corticosterone secretion and GR mRNA levels. Stress 1997; 2: 101-112.

24 Tache YRP, Ducharme JR, Collu R. Pattern of adenohypophyseal hormone changes in male rats following chronic stress. Neuroendocrinology 1978; 26: 208-219.

25 Bassett JR, Cairncross KD. Morphological changes induced in rats following prolonged exposure to stress. Pharmacol Biochem Behav 1975; 3: 411-420.

26 Misilmeri MA, Devine DP. Neuroanatomical sites mediating orphanin FQ-induced modulation of LHPA axis activity. Soc Neurosci Abstract 2000; 26: 435.2.

27 Koster A, Montkowski A, Schulz S, Stube EM, Knaudt K, Jenck F, Moreau JL, Nothacker HP, Civelli O, Reinscheid RK. Targeted disruption of the orphanin FQ/nociceptin gene increases stress susceptibility and impairs stress adaptation in mice. Proc Natl Acad Sci USA 1999; 96: 10444-10449. 